УДК 349.2

DOI https://doi.org/10.32849/2663-5313/2020.8.16

Ніна Гетьманцева,

докт. юрид. наук., доцент, професор кафедри приватного права

Чернівецького начіонального університету імені Юрія Федьковича

Наталія Процьків,

канд. юрид. наук, доцент,

доиент кафедри приватного права

Чернівецького національного університету імені Юрія Федъковича

\title{
ПРАВОВА ПРИРОДА ТРУДОВОГО ТА ЦИВІЛЬНОГО ДОГОВОРІВ
}

Стаття присвячена дослідженню правової природи трудового і иивільного договорів. Констатується: щоб правильно визначити правову природу трудового та иивільного договорів, необхідно звернути увагу на іхні суттєві моменти та характеристики. Звертається увага на мету укладення відповідного договору та засоби, які будуть регламентувати їх укладення. Зауважується, що предмет договору визначає надалі процес організацї роботи (діяльності), що визначається у межах відповідних строків, та є також визначальною ознакою у розмежуванні природи трудового і цивільного договорів. Саме роботодавець в рамках господарської сфери здійснює управління виробниитвом через систему взаємопов'язаних методів залучення до прачі, використовуючи для иього господарсько-дисциплінарну владу. Дана ознака є ключовою для визначення природи трудового договору та його відмежування від иивільного договору. Господарсько-дисииплінарна влада роботодавия проявляється, передусім, у визначенні робочого місия прачівника, режиму роботи та відпочинку; організачї̈ прочесу трудової діяльності та здійсненні ї̈ контролю; організації оплати праці; встановленні організаційних і економічних умов, які необхідні для забезпечення дисиипліни прачі та ї продуктивності. Робиться висновок, що правильно визначена природа трудового договору дозволяє забезпечити прачівника тими гарантіями, що передбачені трудовим законодавством, та сприяти творчому і професійному розвитку прачівника як особистості. Правильно визначена природа цивільного договору дозволяє ефективно виконувати своє призначення як правового засобу упорядкування суспільних відносин. Як елемент механізму правового регулювання иивільний договір дозволяє контрагентам модифікувати особливості змісту договірних зобов'язань з урахуванням ситуаиї, яка склалася. Визначення природи трудового та иивільного договорів має важливе правове значення, оскільки від иього залежить правовий статус особи, який буде визначати не лише права та обов'язки сторін, а й відповідні способи захисту у разі порушення відповідного договору.

Ключові слова: трудовий договір, цивільний договір, працівник, підрядник, замовник, надання послуг.

Постановка проблеми. Важко назвати яке-небудь питання в трудовому чи цивільному праві, яке б настільки приваблювало юристів й так часто висвітлювалося в науково-практичній літературі, як трудовий договір [1, с. 81] та цивільний. Пояснюється це тим принципово важливим місцем, котре займає і продовжує займати даний інститут у регулюванні трудових [1, с. 81] та цивільних відносин. Історично склалося так, що теорія договору стала пріоритетною проблемою цивільного права, а тому і будьякі спроби удосконалити, адаптувати договір до ринкових умов уже як би передбачають цивільно-правовий підхід до реформування будь-якої галузевої науки. Розширення договірної свободи в трудовому праві не пови-

нно сприйматися як розширення сфери дії цивільного права [2, с. 66-67]. Договори й надалі продовжують бути суттєвим складником сучасного суспільства, піддаючись модифікації в результаті запровадження цифрових технологій. Правильно визначена природа договору не тільки слугує ефективним елементом механізму регулювання суспільних відносин між людьми, але й пов'язана зі сферою ствердження і самовираження особи.

Аналіз останніх досліджень та публікацій. Трудовий та цивільний договори $€$ предметом дослідження багатьох вчених. Тому проблемі договору в праві приділена достатня увага представників теорії права, а також окремих галузей права. 
Що стосується трудового та цивільного права, необхідно відзначити праці дослідників теоретичних i науково-практичних проблем трудового та цивільного договору та їх історії: К. Н. Анненкова, І. С. Войтинського, В. М. Гордона, Ю. С. Гамбарова, Д. І. Мейєра, С. Л. Рабіновича-Захарина Л. С. Таля, С. Н. Трубецького, Г. Ф. Шершеневича. Характеризуючи рівень наукового дослідження проблем, пов'язаних з визначенням правової природи трудового і цивільного договорів, потрібно зауважити, що дана проблематика розглядалася в численних працях учених сфери трудового та цивільного права - це, зокрема: В. В. Лазор («Теоретические и социальные аспекты сущности трудового договора и порядок разрешения споров при невыполнении его условий», 2002), О. І. Процевського («Методологічні засади трудового права», 2014), П. Д. Пилипенко («Проблеми теорії трудового права», 1999), А. Б. Грішяк («Договірні зобов'язання із виконання робіт у цивільному праві України», 2013). О. В. Дзери («Договірне право України». Загальна частина, 2008, 2010), Н. С. Кузнецової («Договірне право України». Загальна частина, 2008, 2010), Р. А. Майданика («Проблеми довірчих відносин у цивільному праві» 2002, «Договірне право України». Загальна частина, 2008, $2010)$, Т. В. Боднар («Договірні зобов'язання в цивільному праві: загальні положення», 2007), І.В.Спасибо-Фатєєвої («Договірне право», 2008), С. О. Погрібного («Механізм та принципи регулювання договірних відносин у цивільному праві України», 2009), С. О. Харитонова («Цивільні правовідносини», 2009) та інших вчених.

Метою статті $є$ розкриття правової природи трудового та цивільного договорів як одного з ефективних елементів механізму у регулюванні суспільних відносин між л людьми.

Виклад основного матеріалу. Оскільки римські юристи тільки підійшли до правового розмежування майнового і особистого найму, речі і праці, але так і не довели це розмежування до кінця [3, с. 221], саме поняття «трудовий договір» на ту пору було відсутне в позитивному праві. Вважалося, що юридичним фундаментом усіх договорів про працю $€$ три основних типи договору, які прийшли з римського права дещо у зміненому вигляді: особистий найм, підряд і доручення. Внаслідок цього в науці цивільного права до початку XX ст. сформувалося умовно три позиції щодо правової природи договору найму праці, який регулювався нормами цивільного права [3, с. 334]. Виникнення тру- дового права 3 його центральним інститутом «трудовий договір» пов'язано з обгрунтуванням праці як особливого об'єкта правового регулювання, який не вкладається в рамки цивільно-правової конструкції найму праці, оскільки відрізняється від будь-якого об'єкта цивільних прав. Саме дослідження німецьких вчених мав на увазі Л. С. Таль, коли говорив, що людська особистість «3 погляду сучасних культурних народів, не може бути предметом майнових угод» [4, с. 42-67]. Поняття «трудовий договір» увів у науковий обіг В. Б. Ельяшевич (1907 р.) [5, с. 172-179]. Саму природу трудового договору, як стверджується в юридичній літературі, дослідив Л. С. Таль, який виділяв договори про самостійну (підприємницьку) працю і договори про несамостійну (службову) працю. Саме договір про несамостійну (службову) працю означав трудовий договір як регулятор трудових відносин, що «випливає із підпорядкування робочої сили однієї людини меті і владі іншої людини». Елементом такого договору ставала «обіцянка роботи (обіцянка праці)» [4, с. 25-31]. До характерних ознак трудового договору Л. С. Таль відносив таке: найманий за трудовим договором обіцяе надання своєї робочої сили на користь чужого господарства; від найманого потрібне особисте виконання роботи; із трудового договору випливає обов'язок найманого узгоджувати свою поведінку 3 порядком, встановленим господарем, наймач повинен огороджувати особистість працівника від небезпек, які пов'язані з фактичним перебуванням його в чужій господарській сфері; найманий має право на винагороду за свою працю [4, с. 16]. Пізніше в теорії радянського трудового права названі характеристики були узагальнені й отримали найменування «особистісної, організаційної і майнової» ознак трудового відношення, які розглядалися в нерозривному зв'язку. Дана конструкція, як зауважується в юридичній літературі [4, с. 16], довела свою спроможність як у теоретичному, так і в практичному значенні.

Слід відзначити, що впродовж багатьох років не бралися до уваги інші цивільноправові конструкції, зокрема: договори про надання послуг, авторські договори, реалізація яких пов'язана з використанням праці фізичних осіб. У теорії права склалася певна теоретична ікона стилю, що трудовий договір своїм корінням зародився і, відповідно, виділився із системи цивільно-правових договоpiв, а якщо конкретніше, із договору підряду. Тому у кожному із підручників трудового права у порівняльно-правовому аспекті висвітлюються певні відмінні ознаки, що відрізняють трудовий договір від договору під- 
ряду [6, с. 16]. Сьогодні багата такими порівняльними ознаками судова практика.

«Кожен має право на працю, що включає можливість заробляти собі на життя працею, яку він вільно обирає або на яку він вільно погоджується». Так зазвичай чи не завжди розпочинається викладення мотивувальної частини рішення судів із цивільних справ. Звісно, угоди з громадянами щодо використання їхньої праці можуть укладатися за трудовим або цивільно-правовим договорами, адже ця аксіома випливає з положень Закону України «Про зайнятість населення» (ст. 6). Проте часто практика діяльності територіальних органів Державної служби України 3 питань праці показує тенденцію до підміни трудового договору цивільно-правовим договором. Тому суди зазвичай, відмовляючи у задоволенні позовних вимог, доходять висновку, що у межах спірних правовідносин позивачем не дотримано вимоги норм ст. 24 КЗпП України в частині обов'язкового укладання трудових договорів у письмовій формі та повідомлення центрального органу виконавчої влади з питань забезпечення формування та реалізації державної політики 3 адміністрування єдиного внеску на загальнообов'язкове державне соціальне страхування (ст. 24 КЗпП України).

Щоб у таких ситуаціях правильно визначити правову природу трудового та цивільного договорів, необхідно звернути увагу на їхні суттєві моменти та характеристики. Першорядне значення має мета укладення договору та, відповідно, вибір засобів, які будуть регламентувати укладення відповідного договору: трудового - норми трудового законодавства, цивільно-правового - норми цивільного законодавства. Звісно, конкретний вибір відповідного засобу чітко проявляється на стадії визначення мети (завдань). Від даної обставини залежить, який характер норми буде закладено [6, с. 234]. Адже регулювання взаємовідносин у сфері праці, на відміну від цивільних, уже передбачає забезпечення правовими гарантіями щодо умов праці, робочого часу та часу відпочинку, оплати праці, безпеки праці її охорони.

Отже, метою укладення трудового договору $є$ отримання винагороди у вигляді заробітної плати, «розмір якої залежить від складності та умов виконуваної роботи, професійно-ділових якостей працівника, результатів його праці». У процесі роботи працівник досягає належного професійного рівня. Беручи до уваги ту обставину, що гроші $\epsilon$ особливим різновидом рухомого майна, метою укладення цивільного договору $€$ «отримання певного майнового результату роботи». Мета будь-якого договору визначає його предмет як одну з істотних умов договору. Судова практика також йде таким шляхом. Предметом трудового договору є праця, тоді як предметом цивільноправового договору - виконання стороною визначеного обсягу робіт. Такий висновок зробив Верховний Суд (далі - ВС) у постанові № 127/21595/16-ц. У постанові ВС від 04.07.2018 у справі № 820/1432/17 суд акцентував увагу на тому, що трудовий договір - це угода зі здійснення і забезпечення трудової функції. За трудовим договором працівник зобов'язаний виконувати не якусь індивідуально визначену роботу, а роботу за однією (або декількома) професією, спеціальністю, посадою відповідної кваліфікації, виконувати певну трудову функцію в діяльності підприємства. Проте необхідно акцентувати увагу на тій обставині, що трудова функція, яку буде виконувати працівник за певною професією, спеціальністю, кваліфікацією чи посадою, повинна бути передбачена у штатному розписі підприємства, установи, організації. Штатний розпис - це документ, що встановлює для даного підприємства, установи, організації структуру, штати та посадові оклади працівників [7]. Незважаючи на те, що у трудовому законодавстві не передбачено норми щодо обов'язкової наявності штатного розпису в кожного суб'єкта господарювання, на практиці фахівці Мінпраці розглядають відсутність штатного розпису як порушення вимог законодавства про працю [7], за яке для посадових осіб роботодавців може бути передбачено фінансові санкції у вигляді штрафу (ч. 1 ст. 41 КУпАП). Якщо виходити з логіки змісту вищевказаного листа Мінпраці, то і до самого роботодавця може бути застосована санкція, передбачена абз. 8 ч. 2 ст. 265 КЗпП України. Саме цей документ підлягає вивченню фахівцями Держпраці під час проведення інспекційного відвідування з питань, що стосуються оформлення трудових відносин з найманими працівниками.

Предметом цивільно-правового договору може бути виконання робіт чи надання послуг. Якщо це робота, то повинен бути матеріалізований предмет, а якщо послуга, то вона повинна бути спожита під час надання послуги. А. Б. Гриняк зазначає, що «предметом підрядних договорів $\epsilon$ індивідуалізований результат роботи підрядника, який набуває тієї чи іншої матеріалізованої форми, оскільки робота виконується 3 матеріалів сторін і здається у вигляді, придатному для оцінки. Предметом договорів 3 надання послуг є сам процес надання послуги, а не досягнення матеріалізованого результату. Крім того, основний результат 
при наданні послуг виражається у нематеріальній формі, однак має економічну цінність та корисний ефект для замовника, тоді як результат роботи підрядника завжди виявляється у тій чи іншій матеріальній формі, тобто є уречевленим (матеріалізованим)» [8, с. 21-22]. При цьому необхідно звертати увагу на те, чи визначено у договорі «обсяг виконуваної роботи у вигляді конкретних фізичних величин, які підлягають вимірюванню, що повинні були бути відображені в акті їх приймання; відомості про те, який конкретний результат роботи повинні передати виконавці замовникові; перелік завдань роботи, їі видів, кількісних і якісних характеристик (постанова ВС від 08.05.2018 у справі № 127/21595/16-ц). Необхідно зауважити, що предмет договору визначає надалі процес організації роботи (діяльності), що визначається у межах відповідних строків та $є$ також визначальною ознакою у розмежуванні природи трудового і цивільного договорів. Згідно зі ст. 846 ЦКУ строки виконання роботи або їі окремих етапів встановлюються у договорі підряду. Якщо у договорі підряду не встановлені строки виконання роботи, підрядник зобов'язаний виконати роботу, а замовник має право вимагати пї виконання у розумні строки, відповідно до суті зобов'язання, характеру та обсягів роботи та звичаїв ділового обороту. Таке ж правило передбачено і в ст. 905 ЦКУ: строк договору про надання послуг встановлюється за домовленістю сторін, якщо інше не встановлено законом або іншими нормативно-правовими актами. Строк трудового договору чітко регламентований: ст. 23 КЗпП України передбачає, що договір може бути як безстроковим, що укладається на невизначений строк, так і строковим, що укладається на визначений строк, встановлений за погодженням сторін, та таким, що укладається на час виконання певної роботи. Строк у трудовому праві доцільно розглядати як підставу виникнення, зміни та припинення трудових правовідносин і як спеціальну форму існування у часі конкретного трудового правовідношення [9, с. 115], протягом якого працівник виконує свою трудову функцію за певною професією, спеціальністю, кваліфікацією $з$ підпорядкуванням господарськодисциплінарній владі роботодавця. Саме роботодавець у рамках господарської сфери здійснює управління виробництвом через систему взаємопов'язаних методів залучення до праці, використовуючи для цього господарсько-дисциплінарну владу. Дана ознака є ключовою для визначення природи трудового договору i, відповідно, трудових відносин та розмежування цивільного договору i, відповідно, цивільних відносин. Господарсько-дисциплінарна влада роботодавця проявляється, передусім, у такому:

- визначення робочого місця працівника, під яким розуміють певну ділянку виробничої площі, обладнаної механізмами, інструментами, агрегатами пристосованими для роботи, місце безпосереднього виконання трудової функції [10, с. 484]. Воно характеризується чітко визначеними параметрами: цех, дільниця, відділ, відповідний агрегат [10, с. 484]. Слід звернути увагу, що саме роботодавець повинен проінформувати майбутнього працівника про умови праці на робочому місці, в тому числі про небезпечні і шкідливі виробничі фактори і можливі наслідки їхнього впливу на здоров'я працівника. Нерідко на практиці виникають помилки в оформленні відносин за цивільноправовими договорами. Так постановою від 26 вересня 2018 у справі № 822/723/17 ВС визнав наявність трудових відносин через вищезгадані помилки під час оформлення цивільного договору;

- визначення роботодавцем режиму роботи: початку і закінчення роботи, перерв у роботі, тривалості щоденної роботи, протягом тижня, встановлення режиму відпочинку. Фактично роботодавець веде облік відпрацьованого кожним працівником робочого часу, для чого, як правило, застосовує табель обліку використання робочого часу, який є основним джерелом інформації 3 даного питання. Адже табель - одна з головних підстав для нарахування заробітної плати, складання статистичної та податкової звітності [11, с. 226-227];

- організація процесу трудової діяльності та здійснення контролю за діяльністю працівника, а саме особистим виконанням роботи, передбаченої умовами трудового договору, посадовими інструкціями, правилами внутрішнього трудового розпорядку; перевірка кількості та якості виконаної роботи; нормування та планування роботи, визначення змісту та виду робіт у межах трудової функції. У разі виконання договору підряду чи будь-якого договору на виконання робіт замовника цікавить лише результат. Замовник має право перевіряти хід виконання та якість робіт, але не має права втручатися в діяльність підрядника. Так, у справі № 350/403/16-ц ВС дійшов висновку про наявність трудових відносин між позивачем, який виконував будівельні роботи, та підприємством, оскільки, відповідно до пояснень директора підприємства, останній організовував процес трудової діяльності позивача та інших членів бригади: на власному автомобілі неодноразово 
привозив працівників до місця проведення ремонтних робіт, забезпечував їх будівельними матеріалами та обладнанням для робіт. Суд зазначив, що директор організував трудову діяльність особи, що свідчить про наявність між сторонами трудового договору, а не договору підряду, за яким саме підрядник організовує трудову діяльність і виконує іiі на власний ризик;

- організація оплати праці. Виплачуючи заробітну плату, роботодавець зобов'язаний повідомляти кожного працівника у письмовій формі про складові частини заробітної плати, які належать працівнику до виплати за відповідний період, а також про розміри, підстави утримань та про загальну суму, що підлягає виплаті. При цьому заробітна плата повинна виплачуватися працівникові в робочі дні у строки, встановлені колективним договором, але не рідше двох разів на місяць. Проміжок часу між виплатами повинен становити не більше 16 календарних днів (ст. 115 КЗпП України). Що стосується цивільних договорів, то плата за договором підряду та договорами про надання послуг визначається за домовленістю сторін. У договорі може визначатися або ціна роботи, або спосіб їі визначення. Якщо в договорі підряду не встановлено ціну роботи, то вона встановлюється за рішенням суду на основі цін, що звичайно застосовуються за аналогічні роботи. Найчастіше ціна визначається в грошовому еквіваленті, але може бути й у вигляді зустрічного надання певних послуг чи майна;

- встановлення організаційних і економічних умов, які необхідні для забезпечення дисципліни праці та її продуктивності: визначення та розподіл прав і обов'язків працівників, встановлення відповідного порядку на підприємстві згідно з правилами внутрішнього трудового розпорядку, застосування заходів впливу за порушення трудової дисципліни та притягнення до матеріальної відповідальності за заподіяну шкоду роботодавцю.

У договорі підряду особливе значення має розподіл ризику випадкової загибелі (пошкодження) майна (матеріалів, обладнання, переданої для переробки або обробки речі, іншого використовуваного для виконання договору майна) і самого результату виконаної роботи. Ризик випадкової загибелі (пошкодження) результату виконаної роботи до його прийняття замовником несе підрядник. Даний ризик, покладений за загальним правилом на підрядника, означає втрату підрядником права на оплату виконаної роботи, а також виникнення у нього обов'язку повернути замовнику суму отри- маної передоплати. Тому всі витрати підрядника, зроблені в ході виконання роботи, перетворюються для нього в ніким не компенсовані збитки.

У трудовому договорі особа має статус працівника, який породжує забезпечення певних правових гарантій щодо встановлення умов праці, режиму робочого часу, часу відпочинку, оплати праці, охорони праці тощо. Згідно зі ст. 865 ЦКУ підрядник повинен бути суб'єктом підприємницької діяльності. Якщо особа надає послуги, то вона може мати статус підприємця (ст. 906 ЦКУ) або статус самозайнятої особи, яка провадить незалежну професійну діяльність. Відповідно до підпункту 14.1.226 пункту 14.1 статті 14 Податкового кодексу України незалежна професійна діяльність - це участь фізичної особи у науковій, літературній, артистичній, художній, освітній або викладацькій діяльності, діяльність лікарів, приватних нотаріусів, адвокатів, аудиторів, бухгалтерів, оцінщиків, інженерів чи архітекторів, особи, зайнятої релігійною (місіонерською) діяльністю, іншою подібною діяльністю за умови, що така особа не є працівником або фізичною особою-підприємцем та використовує найману працю не більш як чотирьох фізичних осіб. Отже, за цивільним договором підрядник (виконавець) не є працівником і, як правило, не має жодних правових гарантій, передбачених законодавством. Тому визначення природи трудового та цивільного договорів має важливе правове значення, оскільки від цього залежить правовий статус особи, який буде визначати не лише права та обов'язки сторін, а й відповідні способи захисту у разі порушення відповідного договору.

Говорячи про природу договорів у трудовому і цивільному праві, необхідно зауважити на припиненні їхньої дії. Припинення трудового договору чітко регламентується законодавством 3 дотриманням процедури і порядку звільнення (ст. ст. 22, 36, 40.41, 43, 43-1, 47, 116 КЗпП України).

Цивільно-правові договори припиняються, за загальним правилом, шляхом виконання належним чином. Основним способом розірвання договору є домовленість сторін, тому що вона найбільше відповідає природі договору в силу того, що всі взаємовідносини сторін базуються на основі взаємної згоди. У разі розірвання договору за згодою сторін існує вираження волі всіх сторін, які бажають саме так припинити відносини, що між ними існували. Коли ж договір розривається за ініціативою однієї зі сторін, то на закінчення договірних відносин спрямована воля тільки цієї сторони при запереченні чи пасивності іншої. Розірвання цивільно- 
правового договору - це акт, спрямований на припинення дії частково або повністю не виконаного договору, і тим самим зобов'язання, які випливають з нього, припиняються на майбутне [12, с. 149]. Закон надає замовнику право розірвати договір підряду в будь-який час, відмовившись від його виконання, згідно зі ст. 849 ЦКУ. При цьому він зобов'язаний сплатити підряднику винагороду за виконану частину роботи і відшкодувати йому збитки, завдані розірванням договору, оскільки розірвання договору замовником не пов'язано з будь-якими порушенням з боку підрядника, а зумовлено виключно його бажанням. ВС зазначив, що замовнику законом надано право відмовитися в односторонньому порядку від договору у будь-який час до закінчення роботи, і визначене цією нормою право не може бути обмежено (постанова від 21.08.2019 у справі № 917/1489/18). Проте така відмова замовника від договору підряду, яка за своєю суттю є одностороннім правочином, може бути вчинена до моменту завершення виконання підрядником робіт та із зазначенням відповідних правових підстав. Аналогічне правило передбачено і ст. 907 ЦКУ стосовно договорів про надання послуг.

\section{Висновки}

Трудовий і цивільний договори слугують правовою формою зв'язку учасників правовідносин. Правильно визначена природа трудового договору дозволяє забезпечити працівника тими гарантіями, що передбачені трудовим законодавством, та сприяти творчому і професійному розвитку працівника як особистості.

Правильно визначена природа цивільного договору дозволяє ефективно виконувати своє призначення як правового засобу упорядкування суспільних відносин. Як елемент механізму правового регулювання цивільний договір дозволяє контрагентам модифікувати особливості змісту договірних зобов'язань з урахуванням ситуації, яка склалася.

Визначення природи трудового та цивільного договорів має важливе правове значення, оскільки від цього залежить правовий статус особи, який буде визначати не лише права та обов'язки сторін, а й відповідні способи захисту у разі порушення відповідного договору.

\section{Список використаних джерел:}

1. Басалаева С.П. К вопросу о правовой природе трудового договора. Правоведение. 2003. № 4. C. 81-93.

2. Гетьманцева Н.Д. Договір як підстава застосування закону до конкретних відносин праці. Науковий вісник Чернівещького універсиmету: збірник наук. праць. Вип 187. Чернівці, 2003. C. 66-69.

3. Лушников А.М. Курс трудового права : учебник: в 2-х т. Т.2. Коллективное трудовое право. Индивидуальное трудовое право. Процессуальное трудовое право / Лушников А.М., Лушникова М.В. Москва: Статут, 2009. С. 1151.

4. Таль Л.С. Трудовой договор. Цивилистическое исследование. Москва: Статут, 2006. 539с.

5. Ельяшевич В.Б. Новое движение в области договора о труде. Право. 1907. № 3. С. 172-179.

6. Гетьманцева Н.Д. Особливості правового регулювання трудових відносин : монографія. Чернівці: Технодрук, 2015. 592 с.

7. Щодо штатного розпису : Лист міністерства праці і соціальної політики України від 27.06.2007 № 162/06/187-07. URL: https:// docs.dtkt.ua/doc/1152.291.0? ga $=2.265546376 .668$ 562884.1596390999-1149529834.1584718436 (дата звернення: 08.07.2020).

8. Договори з виконання робіт в цивільному праві України: проблеми теорії і практики : монографія / за заг. ред. А. Б. Гриняка. Київ: НДІ приватного права і підприємництва імені академіка Ф. Г. Бурчака НАПрН України, 2015. 402 с.

9. Чанишева Г.І. Особливості обчислення окремих видів строків у трудовому праві. Актуальні проблеми держави і права. 2011. С. 115-121. URL: http://www.apdp.in.ua/v57/15 pdf (дата звернення: 08.07.2020).

10. Мельницька Н.В. Місце роботи і робоче місце: основні правові ознаки. Університетські наукові записки. 2012. № 1. (41). С. 482-488. URL: irbis-nbuv.gov.ua. pdf (дата звернення: 08.07.2020).

11. Гетьманцева Н.Д., Козуб І.Г. Трудове право України (особлива частина) : навчальний посібник. Чернівці: Чернівецький нац. ун-т, 2014. 504 с.

12. Процьків Н.М. Особливості розірвання договору будівельного підряду. Будівельне право: проблеми теорії $і$ практики : матеріали першої наук. - практ. конф. 2017. С. 147-149.

Nina Hetmantseva, Natalia Protskiv. The legal nature of labor and civil contracts

The article is devoted to the study of the legal nature of labor and civil contracts. It is stated that in order to correctly determine the legal nature of labor and civil contracts, it is necessary to pay attention to their essential points and characteristics. Attention is drawn to the purpose of concluding the relevant agreement and the means that will regulate their conclusion. It is noted that the subject of the contract determines, in the future, the process of organizing work (activity), which is determined within the appropriate terms and, also, is a defining feature when differentiating the nature of labor and civil contracts. It is the employer, within the framework of the economic sphere, that manages production through a system of interrelated methods of attracting to work, using the economic and disciplinary authority for this. This feature is key for 
determining the nature of labor relations and differentiation from a civil contract. The employer's economic and disciplinary power is manifested primarily in the determination of the employee's workplace; work and rest mode; organization of the process of labor activity and implementation of control functions over the activities of the employee; organization of remuneration; establishing the organizational and economic conditions that are necessary to ensure labor discipline and productivity. It is concluded that the correctly defined nature of the employment contract allows the employee to be provided with those guarantees that are provided for by labor legislation and contribute to the creative and professional development of the employee as a person. A correctly defined nature of a civil contract allows you to effectively fulfill its purpose as a legal means of streamlining public relations. As an element of the legal regulation mechanism, a civil contract allows contractors to modify the features of the content of contractual obligations, taking into account the current situation. Determining the nature of labor and civil contracts is of great legal importance, since the legal status of a person depends on this, which will determine not only the rights and obligations of the parties, but also the appropriate methods of protection in case of violation of the relevant contract.

Key words: employment contract, civil contract, employee, contractor, customer, service provision. 